\title{
ANALISIS EFEKTIVITAS PEMASANGAN IKLAN PADA APLIKASI MOBILE DAN FAKTOR- FAKTOR YANG MEMENGARUHINYA
}

\author{
Frisca $^{1}$, R. Puspitasari ${ }^{1}$, S. T. Setyady ${ }^{1}$, Y. Sari ${ }^{1}$, dan Sani M. Isa ${ }^{2}$ \\ ${ }^{1}$ Program Studi Sistem Informasi, Fakultas Ilmu Komputer, Universitas Indonesia, Kampus UI Depok, \\ Jawa Barat, 16424, Indonesia \\ ${ }^{2}$ Program Studi Teknik Informatika, Fakultas Teknologi Informasi, Universitas Tarumanagara, \\ Jl.Letjen.S.Parman No. 1 Blok R Lantai XI Grogol, Jakarta Barat, 11440, Indonesia
}

E-mail: frisca@ui.edu

\begin{abstract}
Abstrak
Perkembangan sistem komunikasi yang semakin cepat membawa dampak yang cukup besar bagi dunia periklanan pada aplikasi mobile. Hal tersebut disebabkan oleh besarnya peluang bagi perusahaan untuk memasarkan produknya dalam bentuk mobile advertisement. Mobile advertisement adalah sebuah iklan yang dapat tampil dalam berbagai bentuk, seperti musik, grafik, suara, atau tulisan melalui terminal telekomunikasi mobile. Salah satu kelebihan mobile advertisement adalah dapat melakukan one-to-one marketing dan mass marketing secara bersamaan. Pada umumnya perusahaan menjalin kerjasama dengan pihak pengembang aplikasi mobile yang telah populer atau paling banyak diunduh, dengan cara memasang iklan pada aplikasi tersebut. Hingga saat ini masih belum diketahui secara jelas mengenai tingkat efektivitas teknik pemasaran produk atau jasa melalui pemasangan iklan pada aplikasi mobile. Efek pemasangan iklan pada aplikasi mobile kepada pengguna aplikasi belum menjadi hal yang dianggap penting oleh sebagian besar perusahaan. Penelitian ini bertujuan untuk melakukan investigasi terhadap efektivitas iklan pada aplikasi mobile serta faktor-faktor yang memengaruhi sikap pengguna mobile terhadap iklan tersebut. Selain itu juga akan dihasilkan rekomendasi mengenai kriteria iklan yang baik. Penelitian ini akan dilakukan dengan menggunakan metode survey dan melihat korelasi antara beberapa parameter terkait periklanan pada aplikasi mobile.
\end{abstract}

Kata Kunci : aplikasi mobile, efektivitas mobile advertisement, kriteria iklan, survey

\begin{abstract}
The development of increasingly rapid communications system brings a considerable impact to the world of advertising on mobile applications. This is due to the large opportunity for companies to market their products in the form of mobile advertisement. Mobile advertisement is an advertisement that can appear in various forms, such as music, graphics, sound, or text through a mobile telecommunication terminal. One of the advantages of mobile advertisement is able to perform oneto-one marketing and mass marketing simultaneously. In general, the company formed a partnership with the developers of mobile applications that have been popular or most downloaded, by placing ads on the application. Until now still not known clearly about the effectiveness of the marketing techniques of products or services through advertising on mobile applications. Effects of advertising on mobile applications to users of the application is not a thing that is considered important by most companies. This study aimed to investigate the effectiveness of advertising on mobile applications and the factors that influence user attitudes toward mobile advertising. They also produced recommendations on the criteria of a good ad. The research will be conducted using the survey method and see the correlation between several parameters related to advertising on mobile applications.
\end{abstract}

Keywords: advertising criteria, mobile applications, survey, the effectiveness of mobile advertisement

\section{Pendahuluan}

Mobile advertisement adalah iklan yang ditampilkan dalam berbagai bentuk, misalnya musik, grafik, suara, atau tulisan, melalui terminal telekomunikasi mobile [1] memiliki kelebihan utama dapat melakukan one-to-one marketing dan mass marketing secara bersamaan [2]. One-to-one marketing berarti iklan yang dikirimkan dapat disesuaikan dengan personalisasi penerima iklan [3], sedangkan mass marketing berarti suatu iklan 
dapat dikirimkan ke banyak penerima sekaligus [4].

Mobile advertisement bukan merupakan hal baru dalam kehidupan kita. Besarnya potensi mobile advertisement membuat banyak perusahaan mengintegrasikannya dengan perencanaan marketing dan periklanan mereka [5]. Periklanan produk melalui SMS (Short Message Service) adalah salah satu bentuk mobile advertisement yang populer dan masih digunakan hingga sekarang [6]. Seiring dengan perkembangan teknologi ponsel, jumlah penggunaan berbagai aplikasi termasuk web browser meningkat yang mana hal ini memicu munculnya periklanan pada mobile website [7]. Bentuk periklanan mobile yang sebelumnya menyamaratakan semua target iklan pun mulai mengalami perubahan dengan adanya segmentasi dan profiling target iklan [8].

Sejak tahun 2000 ada jenis mobile advertisement lain yang dengan cepat mendapatkan kepopuleran, yaitu iklan pada aplikasi ponsel. Dengan adanya smartphone, jenis aplikasi yang dapat dikembangkan semakin luas. Beberapa sistem operasi smartphone populer, seperti iPhone, Android, dan Blackberry, memiliki toko aplikasi yang mampu menampung berbagai aplikasi dalam jumlah besar. Jenis aplikasi tidak lagi terbatas pada web browser dan aplikasi email, tetapi meluas pada berbagai aplikasi jejaring sosial, games, multimedia player, dan lain-lain. Perkembangan smartphone ini pun menarik banyak developer untuk mengembangkan aplikasi bagi smartphone, terutama cross-platform applications untuk meminimalkan biaya pengembangan dan pemeliharaan aplikasi [9].

Aplikasi mobile adalah salah satu pemicu tingginya minat pengguna ponsel untuk beralih ke smartphone dan membuat banyak perusahaan ingin memanfaatkan mobile advertisement, dengan anggapan bahwa pemasangan iklan pada aplikasi mobile yang populer akan meningkatkan peluang terlihatnya iklan oleh pengguna aplikasi. Menurut The Research on Asia Group, Indonesia merupakan pasar terbesar ketiga dalam perkembangan kategori seluler dan menurut data AdMob pada tahun 2008 permintaan mobile advertisement di Indonesia sebesar $22.4 \%$, berada pada peringkat kedua setelah Amerika Serikat. Sementara itu menurut iResearch [10], mobile advertisement di seluruh dunia mencapai \$45.9 miliar pada 2008 dan diperkirakan mencapai \$191.5 miliar pada tahun 2012 dengan persentase peningkatan mencapai $48.84 \%$ setiap tahunnya.

Bagi pengguna aplikasi mobile pada smartphone, munculnya iklan pada aplikasi ternyata dapat membuat pengguna merasa terganggu. Berdasarkan sebuah penelitian di
Korea Selatan [10] yang melibatkan 85 responden, $57.5 \%$ menganggap mobile advertisement tidak menyenangkan dan hanya $10.6 \%$ yang tidak keberatan dengan adanya mobile advertisement.

Sebelumnya telah ada beberapa penelitian mengenai mobile advertisement dengan menggunakan metodologi survey untuk mengumpulkan data bagi berbagai fokus penelitian yang berbeda [10-13]. Penelitian Jung Woo Lee berfokus pada efek dari push type mobile advertisement, sedangkan Dimitris Drossos terbatas pada efektivitas mobile advertisement berdasarkan sudut pandang industry experts. Penelitian lain oleh Ya-Ching Lee berfokus pada faktor yang dapat memengaruhi reaksi pengguna ponsel terhadap mobile advertisement. Salah satu kekurangan dari penelitian ini adalah kategori responden sebagai subjek survey tidak dicantumkan dalam laporan penelitian.

Berdasarkan latar belakang di atas, penelitian ini akan menganalisis faktor-faktor yang dapat memengaruhi efektivitas mobile advertising agar dapat diketahui kriteria iklan yang efektif dan diterima oleh pengguna aplikasi mobile sehingga dapat memberikan keuntungan bagi pihak pengiklan. Metode penelitian yang digunakan metode survey untuk mengumpulkan data-data mengenai mobile advertisement dari para pengguna smartphone, yang kemudian akan dicantumkan dalam kategori responden, dan metode korelasional untuk melihat hubungan antara jenis aplikasi dengan jumlah iklan serta jumlah aplikasi yang diunduh dengan jumlah iklan yang di-klik. Hasil perhitungan korelasi tersebut akan dianalisis untuk mengetahui faktorfaktor yang memengaruhi efektivitas mobile advertising.

Tujuan penelitian ini adalah mengetahui efektivitas suatu iklan pada aplikasi mobile dari sisi pengguna aplikasi dan pihak yang melakukan periklanan. Sedangkan secara spesifik penelitian ini memiliki tujuan untuk mengetahui jenis aplikasi mobile yang paling diminati saat ini, mengetahui efektivitas pemasangan iklan pada aplikasi mobile dilihat dari respons pengguna yang melakukan klik pada iklan di aplikasi mobile tersebut, mengetahui faktor-faktor yang memengaruhi efektivitas mobile advertisement berdasarkan perhitungan dan analisis hasil korelasi beberapa variabel yang didapatkan dari survey, serta memberikan rekomendasi mengenai kriteria iklan yang dapat diterima oleh para pengguna aplikasi mobile pada smartphone.

Efektivitas Iklan Push Type pada Mobile Advertisement. Perkembangan telekomunikasi mobile memicu peningkatan pemasangan iklan 
pada alat komunikasi mobile. Berdasarkan iResearch [10] dan institusi riset pasar di China, laju perkembangan penggunaan mobile advertising dapat terlihat pada gambar 1 .

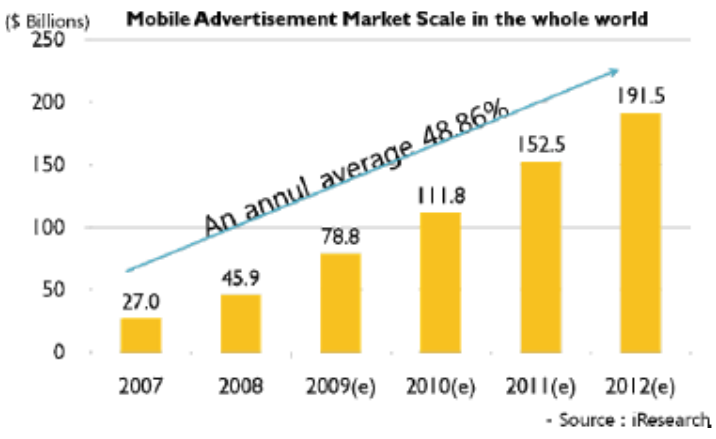

Gambar 1. Skala pasar periklanan mobile di seluruh dunia.

Mobile advertisement terbagi dalam dua tipe, yaitu push type advertisement dan pull type advertisement [10]. Kedua tipe ini memiliki perbedaan karakter masing-masing, yang dapat kembali dibagi-bagi dalam beberapa jenis. Push type advertisement adalah tipe iklan yang muncul dengan paksa (forcible) pada ponsel, pengguna ponsel yang mendapatkan iklan tersebut telah dipilih terlebih dulu dari sekian banyak jumlah pengguna perangkat selular.

Jenis-jenis iklan yang masuk dalam tipe push diantaranya, location based advertisement, time based advertisement, wireless internet connection type, multimedia type advertisement, dan coupun type advertisement. Location Based Advertisement, yaitu pengiriman iklan dilakukan berdasarkan lokasi dari pengguna ponsel. Time Based Advertisement, yaitu pengiriman iklan dilakukan berdasarkan waktu dari pengguna ponsel. Wireless Internet Connection Type Advertisement, yaitu pengiriman iklan dilakukan dengan menginduksi jaringan internet nirkabel. Multimedia Type Advertisement, yaitu iklan yang ditampilkan dengan tambahan gambar, dan/atau animasi selain tampilkan teks iklan. Coupon Type Advertisement, yaitu iklan yang menginduksi partisipasi para pengguna dengan mengirimkan pesan singkat berisi URL yang mengacu pada situs yang menyediakan kupon yang bisa diunduh oleh orang yang berminat.

Tipe kedua adalah Pull Type Advertisement, yaitu tipe iklan yang bisa memengaruhi pengguna untuk menjadi tertarik pada iklan dan direktori iklan tersebut. Jenis-jenis iklan yang termasuk dalam tipe pull ini antara lain directory advertisement, banner advertisement, page insertion advertisement, serta mobile code. Directory Advertisement, yaitu pemasangan iklan dengan memasukkan menu kategori iklan dalam konten internet nirkabel. Banner Advertisement, yaitu pemasangan iklan dengan memasukkan gambar iklan dalam konten internet nirkabel. Page Insertion Advertisement, yaitu pemasangan iklan dilakukan dengan memasukkan halaman iklan tertentu saat menggunakan layanan internet nirkabel tertentu. Mobile Code, yaitu iklan interaktif yang terhubung dengan halaman internet nirkabel yang memungkinkan pengguna melihat informasi harga dan detail lainnya, beserta produk lain yang terkait setelah pengguna mengambil gambar kode yang terdapat pada media cetak seperti koran dan majalah dengan kamera dari ponsel pengguna tersebut.

Tipe iklan lainnya adalah kategori iklan yang tidak termasuk dalam tipe push atau pull atau kategori iklan yang masuk dalam kedua tipe tersebut. Jenis iklan yang masuk dalam tipe lain yaitu loading screen advertisement dan ring back tone (RBT) advertisement. Loading Screen Advertisement, yaitu pemasangan iklan pada layar ponsel saat proses loading akan dikenai potongan harga per bulannya. Ring Back Tone (RBT) Advertisement, yaitu pemasangan iklan dengan memasukkan iklan sebagai RBT saat menelepon.

Efek yang ditimbulkan dari tipe iklan push diantaranya contant effect, psychological effect, dan buying action effect. Contant Effect, yaitu efek yang diukur dari sejauh mana konsumen melakukan kontak dengan iklan. Psychological Effect, yaitu efek yang diukur dari sekuat atau sebaik apa impresi yang dihasilkan oleh para konsumen. Buying Action Effect, yaitu efek untuk mengetahui apakah seorang konsumen melakukan pembelian karena kebutuhan atau hanya aksi sesaat saja.

Sebelumnya telah dilakukan suatu riset tentang pemasangan iklan dengan tipe push [10] yang melibatkan $52.6 \%$ konsumen ber-gender wanita, sedangkan $42.4 \%$ sisanya ber-gender pria. Berdasarkan usia, konsumen terbanyak berasal dari kategori usia 20-an tahun. Sedangkan hasil yang didapat mengenai efek dari iklan adalah sebagian besar berpendapat tidak senang dengan adanya iklan tersebut, yaitu sebanyak $57.7 \%$. Sedangkan konsumen yang merasa senang hanya sebesar $10.6 \%$. Hasil penelitian dapat terlihat pada tabel I. 
TABEL I

STATISTIK KARAKTERISTIK POPULASI RESPONDEN

\begin{tabular}{|c|c|c|c|c|c|c|}
\hline \multirow[t]{3}{*}{ Gender } & Classification & \multicolumn{2}{|c|}{ Male } & \multicolumn{3}{|c|}{ Female } \\
\hline & Respondent & \multicolumn{2}{|c|}{36} & \multicolumn{3}{|c|}{49} \\
\hline & Percent (\%) & \multicolumn{2}{|c|}{42.4} & \multicolumn{3}{|c|}{57.6} \\
\hline \multirow[t]{3}{*}{ Age } & Classification & $\begin{array}{l}\text { Less than } 20 \\
\text { years }\end{array}$ & Twenty & Thirty & \multicolumn{2}{|c|}{ Forty } \\
\hline & Respondent & 5 & 41 & 25 & \multicolumn{2}{|c|}{14} \\
\hline & Percent (\%) & 5.9 & 48.2 & 29.4 & \multicolumn{2}{|c|}{16.5} \\
\hline \multirow[t]{3}{*}{ Scool Career } & Classification & $\begin{array}{l}\text { High school } \\
\text { graduate }\end{array}$ & $\begin{array}{c}\text { Studying } \\
\text { University }\end{array}$ & $\begin{array}{l}\text { University } \\
\text { graduate }\end{array}$ & \multicolumn{2}{|c|}{ Post-graduate degree } \\
\hline & Respondent & 15 & 16 & 36 & \multicolumn{2}{|c|}{18} \\
\hline & Percent (\%) & 17.6 & 18.8 & 42.4 & \multicolumn{2}{|c|}{21.2} \\
\hline \multirow{3}{*}{$\begin{array}{l}\text { Good feeling degree } \\
\text { about mobile } \\
\text { advertisement }\end{array}$} & Classification & Very unpleasent & $\begin{array}{c}\text { Unpleasen } \\
t\end{array}$ & So-so & Good & Very good \\
\hline & Respondent & 9 & 40 & 27 & 8 & 1 \\
\hline & Percent (\%) & 10.6 & 47.1 & 31.8 & 9.4 & 1.2 \\
\hline
\end{tabular}

Faktor-Faktor yang Memengaruhi Efektivitas Mobile Advertising. Pemasangan iklan mobile menjadi salah satu hal yang cukup populer dari mobile commerce, terutama dalam bentuk SMS advertising, tetapi masih sedikit yang diketahui tentang efektivitas metode iklan ini dan faktor yang mendukung keberhasilannya. Hasil penelitian dari Drossos dan Giaglis tahun 2006 [12] menyebutkan bahwa terdapat empat faktor utama yang memengaruhi efektivitas mobile advertising yaitu, Campaign Strategy, Source, Targeting, dan Creative Development Campaign Strategy.

Tanggapan Responden terhadap Mobile Advertising. Internet advertising dapat digunakan untuk mengidentifikasi profil dan perilaku individu masing-masing konsumen. Di lain pihak, mobile advertising kini telah mengatasi hambatan dari internet yang bersifat fixed-line, terkait dengan perilaku konsumen yang bersifat mobile [13]. Ponsel adalah perangkat yang sangat personal, maka mobile advertisement yang ditampilkan harus bersifat lebih personal, juga ditampilkan dalam berbagai bentuk.

Hasil penelitian Tsang et. al., pada tahun 2004 [14] mengindikasikan bahwa tingkat penerimaan responden terhadap mobile advertising masuk dalam kategori negatif, atau dengan kata lain responden cenderung untuk tidak suka dengan munculnya mobile advertising pada aplikasi mobile yang mereka gunakan.

Personalized Advertisement pada iDTV, Internet, dan Mobile Device. Kemajuan dari media digital ditandai dengan meningkatnya saluran periklanan yang interaktif seperti internet, iDTV, dan aplikasi mobile yang sangat berpengaruh terhadap sektor periklanan [15]. Teknologi baru seperti internet, iDTV, dan aplikasi mobile menawarkan iklan dalam cara yang berbeda dan lebih atraktif daripada iklan yang dipasang secara tradisional [11]. Banyak pengguna mobile mencoba untuk menghindari iklan yang menganggu seperti pop up banner. Adanya issue tersebut membuat para developer mencari teknik baru agar iklan yang dibuatnya dapat diterima oleh pengguna mobile. Teknik baru seperti personalized advertisement dan membangun hubungan dengan customer bermanfaat untuk memperbaiki iklan yang telah dipasang sebelumnya sehingga dipercaya dapat mengurangi tingkat pengabaian iklan [11]. Teknik personalized advertisement dikembangkan di dalam suatu sistem yang mengkombinasikan multiple platform seperti iDTV, internet, dan aplikasi mobile. Customer dapat menerima personalized advertisement pada tiga platform yaitu iDTV, internet, dan personal mobile device. Personalization server menentukan jenis iklan yang cocok untuk customer tertentu berdasarkan pada user profile mereka. User profile yang diperoleh kemudian diekstrak dan dibandingkan dengan metadata iklan untuk kemudian diolah menjadi rekomendasi iklan yang dapat diterima oleh customer [11].

Korelasi Pearson Product Moment. Koefisien korelasi merupakan suatu ukuran hubungan di antara dua variabel. Koefisien korelasi mengambil nilai di antara -1.0 dan +1.0 . Tanda plus menunjukkan bahwa hubungan yang terjadi di antara kedua variabel adalah positif dan tanda minus menunjukkan bahwa hubungan yang terjadi di antara kedua variabel adalah negatif. Dua buah variabel dikatakan tidak memiliki hubungan jika nilai dari koefisien korelasinya adalah 0 .

Pearson product moment correlation coefficient disimbolkan dengan huruf $r$. Terdapat empat Pearson $r$ formula yang dapat digunakan untuk menghitung nilai dari koefisen korelasi [16][17]. Pada penelitian ini digunakan raw score formula seperti pada persamaan 1: 


$$
r_{x y}=\frac{n \sum(x y)-\sum x \sum y}{\sqrt{\left(n \sum x^{2}-\left(\sum x\right)^{2}\right) \cdot\left(n \sum y^{2}-\left(\sum y\right)^{2}\right.}}
$$

Penelitian yang dilakukan oleh Ya-Ching Lee [13] tidak melakukan kategorisasi terhadap responden. Hal itu dapat dianggap sebagai kekurangan karena sampling yang diambil untuk responden sebuah survey harus memiliki kejelasan terhadap target responden penelitian. Misalnya, apakah responden berasal dari kalangan akademik atau non-akademik, atau berasal dari range usia tertentu.

Menurut penelitian yang dilakukan oleh Jung Woo Lee [10] pemasangan iklan dengan push type tidak efektif, sebab hasil dari penelitian menunjukkan tingkat penerimaan pengguna ponsel terhadap iklan sangat rendah, yaitu hanya sebesar $10.6 \%$. Sedangkan menurut Drossos [12] faktor-faktor yang dapat memengaruhi efektivitas mobile advertisement antara lain adalah strategi promosi, merek pemasang iklan, pemilihan target penerima iklan, dan kreativitas pengembangan iklan [12].

Strategi promosi adalah strategi yang dijalankan oleh pemasang iklan, dengan memikirkan cara mempromosikan produknya dibandingkan dengan produk lain, dan bagaimana cara menyusun pesan untuk menyampaikan superioritas produk dan tujuan promosi. Merek pemasang iklan juga menjadi faktor efektivitas sebab merek yang punya reputasi memiliki probabilitas mendapat respons yang lebih besar, dan lebih mudah mendapatkan izin penyaluran iklan melalui SMS dibandingkan dengan merek yang belum begitu dikenal masyarakat. Pemilihan target penerima iklan dilakukan dengan melakukan eksaminasi fitur-fitur pilihan para pengguna dalam basis data, melihat perilaku pembelian yang dilakukan konsumen, dan minat para pengguna. Pemilihan target memungkinkan pengguna akan mendapat kesempatan menerima SMS iklan yang sesuai dengan minatnya, dan melakukan pembelian setelah melihat iklan menjadi lebih tinggi. Faktor terakhir adalah kreativitas pengembangan iklan, yang dilakukan dengan mengembangkan iklan dengan format pesan dan struktur yang berbeda dari iklan yang lain. Semakin kreatif bentuk dan format iklan, akan meningkatkan ketertarikan pengguna untuk melihat dan membeli produk yang diiklankan tersebut.
Dari kedua pendapat tersebut, dapat dikatakan bahwa untuk melakukan pemasangan iklan yang efektif sebaiknya menghindari pemilihan push type, dan pemasangan iklan sebaiknya memperhatikan keempat faktor yang telah disebutkan sebelumnya.

Berdasarkan hasil dari penelitian [10][14], dapat diketahui bahwa konsumen biasanya memberikan respons yang negatif terhadap iklan pada aplikasi mobile. Sedangkan penelitian yang dilakukan Lin [18] dan Unni \& Harmon [19] menyatakan bahwa pengguna mobile yang berasal dari usia muda atau remaja akan lebih menerima kehadiran mobile advertising dibandingkan dengan pengguna yang berasal dari usia tua. Selain itu, beberapa studi lain menemukan bahwa situational context menjadi faktor penting yang memengaruhi reaksi pengguna mobile terhadap iklan pada aplikasi mobile [13].

\section{Metodologi}

Riset ini bertujuan untuk melakukan analisis terhadap faktor-faktor yang memengaruhi efektivitas mobile advertising dilihat dari dua jenis korelasi untuk mengetahui kriteria iklan yang efektif dan dapat diterima oleh para pengguna aplikasi smartphone. Korelasi pertama yang digunakan adalah hubungan antara jenis aplikasi dengan jumlah iklan pada aplikasi tersebut. Sedangkan korelasi kedua adalah hubungan antara jumlah pengunduhan aplikasi dengan jumlah klik iklan pada aplikasi tersebut. Peneliti akan menggunakan dua metode, yaitu correlational research dan survey. Korelasi yang telah peneliti sebutkan sebelumnya akan dinilai dari hasil survey yang peneliti lakukan.

Pengerjaan riset ini terbagi dalam empat tahap utama, yaitu studi literatur, analisis kondisi mobile advertising saat ini, penentuan parameter dan pertanyaan survey, serta penentuan metode analisis. Gambar 2 menampilkan langkah-langkah yang akan peneliti lakukan dalam pengerjaan riset ini.

Fase pertama adalah studi literatur dan proses tinjauan pustaka dari berbagai sumber seperti buku, jurnal, konferensi, dan lain-lain terkait dengan objek penelitian. Studi literatur dan proses tinjauan pustaka ini bertujuan untuk menambah pengetahuan terkait dengan objek yang sedang diteliti. 


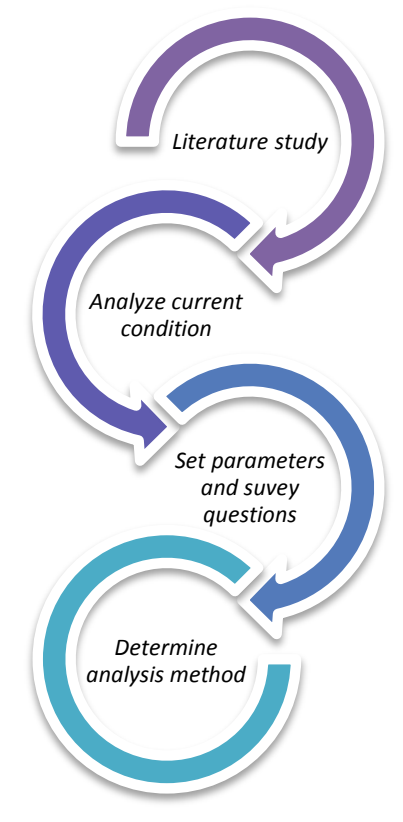

Gambar 2. Tahapan riset.

Output dari fase pertama adalah pehamaman terhadap ruang lingkup penelitian dan perolehan informasi serta pengetahuan baru terkait objek penelitian yang nantinya akan digunakan pada tahap selanjutnya.

Fase kedua adalah menganalisis kondisi iklan saat ini pada aplikasi mobile. Pada fase ini akan dilakukan peninjauan terhadap iklan-iklan yang telah ada pada aplikasi mobile, mencari tahu karakteristik iklan yang sering muncul pada aplikasi mobile tertentu, serta mencari tahu persentase jenis dan jumlah aplikasi mobile yang telah diunduh pengguna smart phone saat ini. Fase kedua ini juga akan meninjau kondisi pasar smartphone dan aplikasi mobile yang ada dan telah diunduh oleh pengguna smartphone. Peninjauan kondisi pasar smartphone dapat dilakukan dengan mencari tahu demografi pengguna yang seperti apakah yang menjadi target pemasang iklan pada suatu aplikasi mobile serta jenis ponsel smartphone apa saja yang dapat dijadikan media yang menarik untuk beriklan.

Pada fase ketiga, akan dilakukan ekstrak data dari analisis yang telah lebih dulu dilakukan di fase sebelumnya. Data yang diekstrak antara lain adalah karakteristik iklan yang dipasang pada aplikasi mobile, jenis aplikasi, dan golongan target pasar. Data ini kemudian akan dijadikan acuan untuk mulai membuat pertanyaan-pertanyaan yang akan dimuat dalam lembar survey, untuk dibagikan pada para responden. Dalam penyusunan pertanyaan, akan digunakan closed- ended question untuk memudahkan proses analisis di fase terakhir. Survey yang akan dilakukan pada fase ini dibuat dengan tujuan ingin mengetahui bagaimana korelasi antara jenis aplikasi dan jumlah iklan yang dipasang pada aplikasi tersebut. Jenis aplikasi yang akan diamati pada fase ini bergantung dari golongan target pasarnya. Untuk prediksi awal, diasumsikan bahwa kepopuleran jenis aplikasi akan memengaruhi jumlah iklan yang terpasang pada aplikasi tersebut. Namun, asumsi ini belum terbukti, dan untuk dapat membuktikannya akan disebarkan kuisioner survey, yang ditujukan bagi para pengguna smartphone dari segala usia. Responden dipilih dari rentang usia 17-24 tahun, 25-32 tahun, dan lebih dari 32 tahun agar hasil yang diperoleh lebih akurat dan mewakili setiap golongan.

Survey yang dilakukan pada fase ini hanyalah survey pendahuluan, yang menghasilkan data untuk menjadi acuan dalam memilih target survey tahap berikutnya.

Fase keempat dalam penelitian ini akan serupa dengan fase sebelumnya, yaitu kegiatan survey tahap dua. Hasil dari survey sebelumnya adalah data mengenai jenis aplikasi yang paling banyak diminati pengguna smartphone dan dipilih perusahaan untuk memasang iklan. Setelah jenis aplikasi diketahui maka langkah selanjutnya adalah meninjau berapa jumlah pengunduh aplikasi tersebut. 
48 Journal of Information Systems, Volume 7, Issues 1, April 2011

TABEL II

INTERPRETASI UKURAN KORELASI

\begin{tabular}{ll}
\hline \multicolumn{1}{c}{ Size of Correlation } & \multicolumn{1}{c}{ Interpretation } \\
\hline 0.90 to $1.00(-0.90$ to -1.00$)$ & Very high positive (negative) correlation \\
0.70 to $0.90(-0.70$ to -0.90$)$ & High positive (negative) correlation \\
0.50 to $0.70(-0.50$ to -0.70$)$ & Moderate (negative) correlation \\
0.30 to $0.50(-0.30$ to -0.50$)$ & Low positive (negative) correlation \\
0.00 to $0.30(0.00$ to -0.30$)$ & Very low positive (negative) correlation \\
\hline
\end{tabular}

TABEL III

Statistik Hasil SURVEI

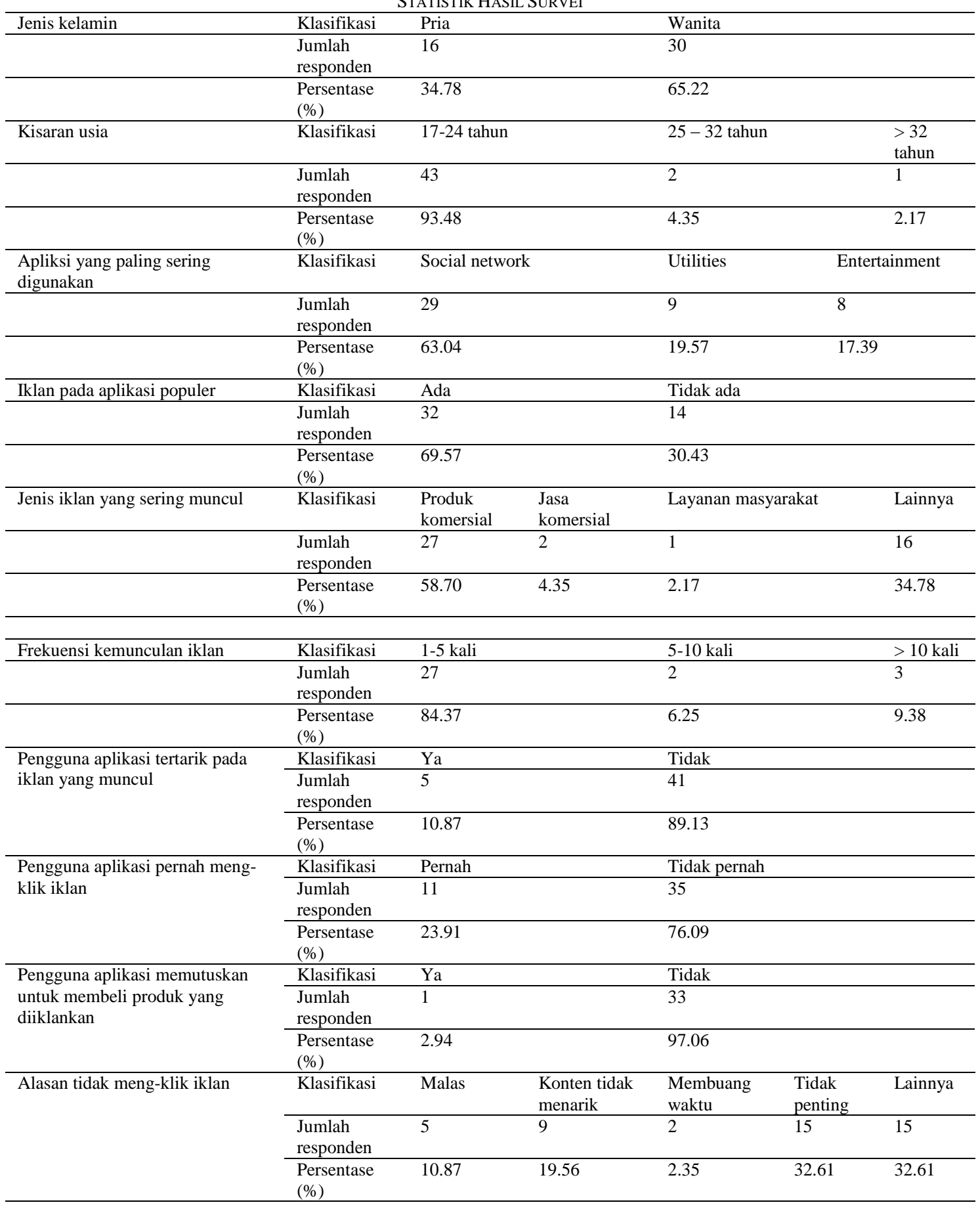


Jenis aplikasi yang dihasilkan dari survey sebelumnya akan menjadi target analisis survey pada fase keempat ini. Survey ini bertujuan untuk mencari korelasi antara jumlah pengunduhan aplikasi dengan jumlah pengguna yang mengklik iklan pada aplikasi tersebut. Jumlah pengunduhan menjadi faktor analisis sebab melalui angka ini akan terlihat apakah sebuah aplikasi yang menampilkan banyak iklan masih tetap diminati oleh para pengguna. Terdapat asumsi-asumsi yang mengindikasikan reaksi pengguna aplikasi tidak begitu positif terkait dengan banyaknya iklan yang muncul di halaman aplikasi yang mereka gunakan.

Setelah mengetahui jumlah pengunduhan, akan ditinjau seberapa banyak pengguna yang mengklik iklan yang tampil pada halaman aplikasi yang sedang mereka gunakan. Sebab angka jumlah pengunduh yang tinggi belum bisa dipastikan akan memengaruhi hasil jumlah iklan yang di-klik oleh pengguna. Prediksi awal penelitian ini adalah walaupun suatu aplikasi diunduh oleh banyak orang, belum tentu iklan yang terpampang pada halaman aplikasi juga menarik perhatian pengguna untuk kemudian mengklik iklan tersebut. Hasil survey kedua ini diharapkan dapat menjawab ketidakpastian hubungan jumlah pengunduh dengan jumlah iklan yang di-klik. Untuk lebih melihat tingkat penerimaan responden terhadap iklan, akan dilakukan analisis reaksi dari para responden survey. Reaksi responden pada pemasangan iklan pada aplikasi mobile bervariasi, ada tipe responden yang sama sekali tidak membaca apa iklan yang ada pada aplikasi mobile tersebut, ada pula responden yang membaca lalu tertarik, tetapi karena ada rasa takut akan ancaman virus yang bisa langsung menyerang mobile phone mereka maka iklan tersebut tidak di-klik, dan reaksi responden yang terakhir adalah responden langsung tertarik saat melihat iklan yang muncul pada aplikasi, lalu mengklik iklan tersebut untuk tahu informasi lebih jauh. Survey ini dijalankan dengan asumsi bahwa banyaknya jumlah pengguna yang mengklik iklan pada aplikasi menandakan bahwa pemasangan iklan pada aplikasi mobile bersifat efektif.

Perhitungan korelasi terbagi menjadi lima hubungan korelasi yang terjadi berdasarkan besar atau ukuran korelasi yang diperoleh [16]. Adapun hubungan korelasi tersebut dapat dilihat pada tabel II.

Semua hasil survey yang diperoleh pada penelitian ini akan dimanfaatkan untuk menjadi acuan bagi perusahaan yang ingin mulai memperluas cara pemasaran produk maupun jasa yang mereka hasilkan, melalui pemasangan iklan pada aplikasi mobile. Hasil kedua survey akan menunjukkan rangkaian kriteria pemasangan iklan yang efektif pada aplikasi mobile, terlihat dari jumlah klik iklan pada jenis aplikasi tertentu. Kriteria pemasangan iklan dapat menjadi acuan bagi perusahaan saat merencanakan pemasangan iklan pada aplikasi mobile, agar perencanaan dapat diarahkan untuk mencapai hasil yang efektif dan efisien [5].

Efektivitas iklan juga akan ditentukan dari sejauh mana reaksi responden terhadap iklan pada aplikasi mobile yang mereka gunakan. Bila pengguna aplikasi memperlihatkan reaksi menolak dan merasa sangat terganggu dengan adanya iklan yang terus menerus muncul di halaman aplikasi yang sedang mereka pakai, maka popularitas aplikasi akan mengalami penurunan dan iklan bersifat tidak efektif. Bila reaksi pengguna aplikasi tidak signifikan, dalam arti responden tidak keberatan banyak iklan muncul pada halaman aplikasi yang mereka gunakan, tetapi juga tidak meng-klik iklan dan hanya meneruskan pemakaian aplikasi, maka popularitas aplikasi tidak terpengaruh tetapi pemasangan iklan masih terhitung tidak efektif. Sedangkan bila responden bereaksi positif dengan merasa tertarik saat melihat iklan yang muncul pada aplikasi, lalu meng-klik iklan tersebut untuk melakukan pembelian lebih lanjut, maka pemasangan iklan pada aplikasi mobile telah berjalan efektif.

\section{Hasil Analisis}

Representasi Hasil Survey. Berikut adalah representasi hasil survey yang digambarkan dalam tabel III dan dengan menggunakan pie chart.

Tabel III menunjukkan representasi statistik hasil survey yang dilakukan kepada 46 responden secara online dengan jumlah responden laki-laki sebanyak 16 orang dan responden wanita sebanyak 30 orang. Responden berasal dari kalangan usia 17-24 tahun, 25-32 tahun, dan lebih dari 32 tahun.

\section{Jenis Kelamin}

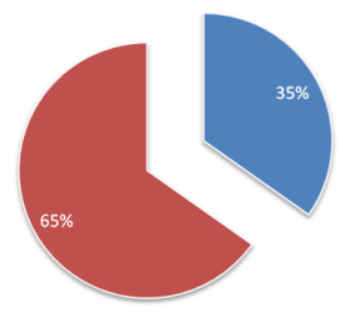

In Pria

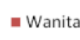

Gambar 3. Klasifikasi responden berdasarkan jenis kelamin. 
Gambar 3 menunjukkan bahwa jumlah responden pria lebih sedikit dibandingkan dengan jumlah responden wanita. Responden wanita sebesar $65 \%$ dan responden pria sebesar $35 \%$ dari jumlah keseluruhan responden.

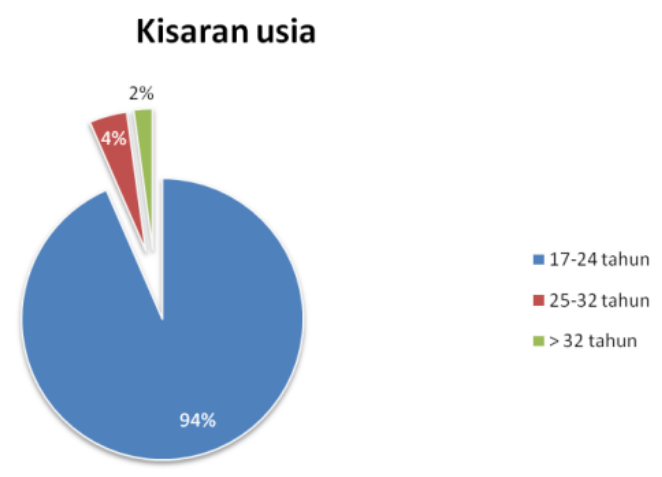

Gambar 4. Klasifikasi responden berdasarkan kisaran usia.

Gambar 4 menunjukkan bahwa jumlah responden yang berasal dari kisaran usia 17-24 tahun mendominasi kisaran usia lainnya. Responden yang berasal dari kisaran usia 17-24 tahun sebesar 94\% dari jumlah keseluruhan responden, sedangkan responden yang berasal dari kisaran usia 25-32 tahun sebesar 4\% dan responden yang berasal dari kisaran usia $>32$ tahun sebesar $2 \%$.

\section{Aplikasi yang paling sering digunakan}

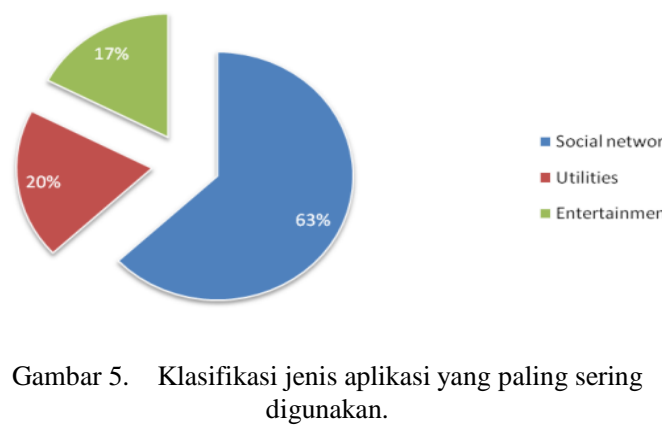

Gambar 5 menunjukkan bahwa jenis aplikasi yang paling sering digunakan adalah aplikasi social network dengan persentase sebesar $63 \%$, disusul dengan aplikasi utilities dengan persentase sebesar $20 \%$ dan aplikasi entertainment dengan persentase sebesar $17 \%$.

Gambar 6 menunjukkan bahwa 70\% aplikasi populer memuat iklan di dalamnya, sedangkan hanya $30 \%$ aplikasi populer yang tidak memuat iklan.

\section{Iklan pada aplikasi populer}

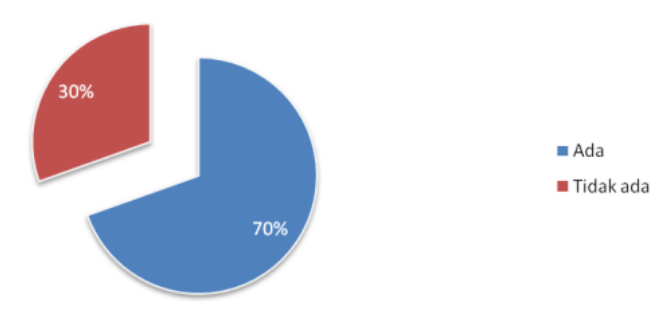

Gambar 6. Klasifikasi keberadaan iklan pada aplikasi populer.

Jenis iklan yang sering muncul

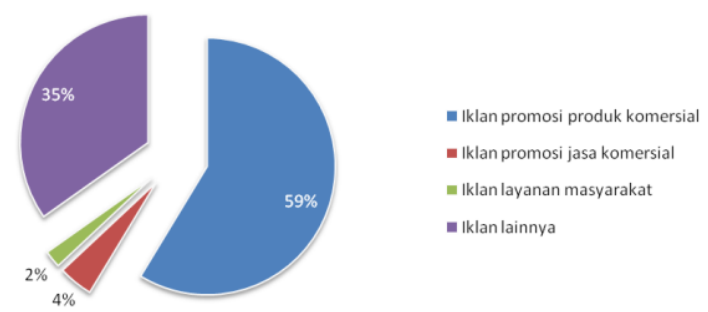

Gambar 7. Klasifikasi jenis iklan yang paling sering muncul.

Gambar 7 menunjukkan bahwa jenis iklan yang paling sering muncul adalah iklan promosi produk komersial dengan persentase sebesar 59\%, disusul dengan jenis-jenis iklan lainnya sebesar $35 \%$. Keberadaan iklan promosi jasa komersial hanya sebesar $4 \%$ dan iklan layanan masyarakat sebesar $2 \%$.

\section{Frekuensi kemunculan iklan}

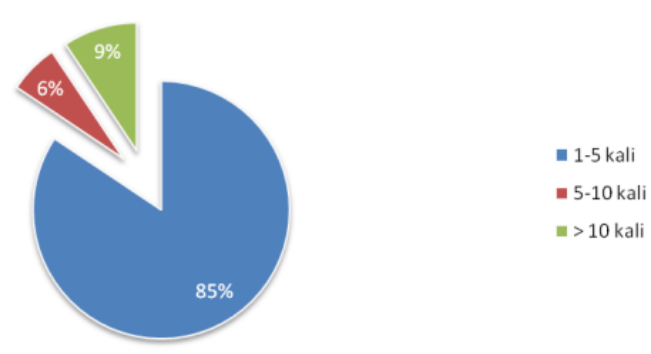

Gambar 8. Frekuensi kemunculan iklan.

Gambar 8 menunjukkan bahwa frekuensi kemunculan iklan yang mendominasi adalah sebanyak 1-5 kali dengan persentase sebesar $85 \%$, disusul dengan frekuensi $>10$ kali sebesar $9 \%$ dan 5-10 kali sebesar 6\%. 


\section{Pengguna aplikasi tertarik pada iklan yang} muncul

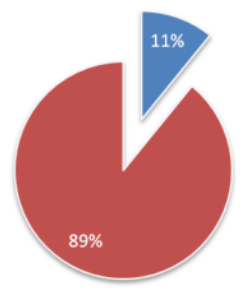

- Ya

- Tidak

Gambar 9. Klasifikasi responden berdasarkan ketertarikan pada iklan.

Gambar 9 menunjukkan bahwa jumlah responden yang merasa tertarik pada iklan hanya sebesar $11 \%$ dari jumlah keseluruhan responden, sedangkan $89 \%$ responden menyatakan tidak tertarik pada iklan di aplikasi mobile mereka.

Gambar 10 menunjukkan bahwa jumlah responden yang pernah meng-klik iklan pada aplikasi mobile mereka hanya sebesar $24 \%$ dari jumlah keseluruhan responden, sedangkan $76 \%$ responden menyatakan tidak pernah meng-klik iklan pada aplikasi mobile mereka.

\section{Pengguna aplikasi pernah mengklik iklan}

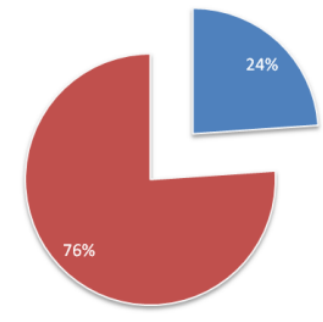

- Pernah - Tidak pernah

Gambar 10. Klasifikasi responden berdasarkan pernah tidaknya meng-klik iklan.

\section{Pengguna aplikasi memutuskan membeli} produk yang diiklankan

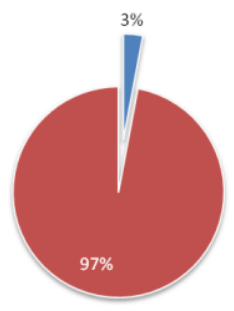

Gambar 11. Klasifikasi responden berdasarkan keputusan untuk membeli produk yang diiklankan.

Gambar 11 menunjukkan bahwa jumlah responden yang memutuskan untuk membeli produk yang telah diiklankan pada aplikasi mobile mereka hanya sebesar 3\% dari jumlah keseluruhan responden, sedangkan $97 \%$ responden memutuskan untuk tidak membeli produk yang telah diiklankan.

Gambar 12 menunjukkan bahwa jumlah responden yang memutuskan untuk tidak mengklik iklan karena merasa iklan tersebut tidak penting yaitu sebesar $33 \%$ dari jumlah keseluruhan responden. $19 \%$ responden menyatakan konten iklan tidak menarik untuk diklik, $11 \%$ responden menyatakan malas untuk meng-klik iklan, dan $4 \%$ responden menyatakan bahwa meng-klik iklan tersebut hanya akan membuang waktu mereka. Sedangkan 33\% responden memiliki berbagai alas an lain untuk tidak meng-klik iklan yang muncul.

Analisis Survey Pertama. Jawaban yang telah diperoleh dari para responden selanjutnya akan analisis untuk mengetahui tujuan dari adanya survey pertama ini. Analisis dilakukan dengan cara menghitung korelasi antara jenis aplikasi yang terdapat pada aplikasi mobile dengan jumlah iklan yang terpasang pada aplikasi tersebut. Selanjutnya akan dihitung juga korelasi per jenis aplikasi yang terdapat pada pertanyaan survey. Untuk aplikasi pertama yang akan dihitung korelasinya dengan jumlah iklan yang terpasang pada aplikasi tersebut adalah aplikasi social networks seperti UberSocial, Facebook, dan Twitter. Dengan menggunakan rumus persamaan 2 [17]:

$$
r_{x y}=\frac{n \sum(x y)-\sum x \sum y}{\sqrt{\left(n \sum x^{2}-\left(\sum x\right)^{2}\right) \cdot\left(n \sum y^{2}-\left(\sum y\right)^{2}\right.}}
$$

Di mana $r$ adalah ukuran korelasi yang akan dihitung, variabel $x$ menyatakan jenis aplikasi pada smartphone dan variabel y menyatakan jumlah iklan akan dilakukan perhitungan untuk mendapatkan ukuran korelasi antara aplikasi social network dan jumlah iklan yang terdapat pada aplikasi tersebut. Perhitungan hasil korelasi dapat dilihat pada perhitungan berikut:

$$
\begin{aligned}
& r_{x y}=\frac{46 \times 97-29 \times 143}{\sqrt{46 \times 29-(29)^{2} \times\left(46 \times 903-(143)^{2}\right.}} \\
& r_{x y}=\frac{315}{\sqrt{(493 \times 20449}}=0.09
\end{aligned}
$$

Dari perhitungan di atas, diperoleh nilai korelasi sebesar 0.09. Hal ini mengindikasikan bahwa hubungan antara jenis aplikasi social networks dengan jumlah iklan yang terpasang 
pada aplikasi tersebut adalah very low positive correlation. Dengan adanya hubungan tersebut, dapat diterjemahkan bahwa jumlah iklan yang terpasang pada social networks tidak terlalu memiliki hubungan dengan aplikasi social networks.

\section{Alasan tidak mengklik iklan}

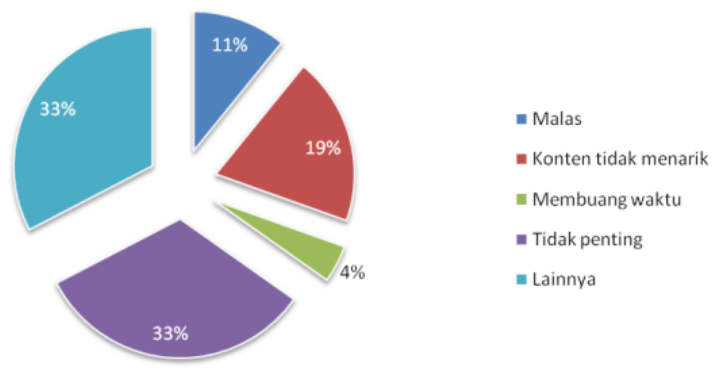

Gambar 12. Klasifikasi responden berdasarkan alasan tidak meng-klik iklan.

Untuk aplikasi kedua yang akan dihitung korelasinya dengan jumlah iklan yang terpasang adalah aplikasi utilities seperti Opera Mini, $e B u d d y$, dan lain-lain. Perhitungan menggunakan rumus pada persamaan 2 , diperoleh:

$$
\begin{gathered}
r_{x y}=\frac{46.36-18.141}{\sqrt{46 \times 36-(18)^{2} \times\left(46 \times 855-(141)^{2}\right.}} \\
r_{x y}=\frac{-882}{\sqrt{1332 \times 19449}}=-0.173
\end{gathered}
$$

Dari perhitungan di atas, diperoleh nilai korelasi sebesar -0.173. Hal ini mengindikasikan bahwa hubungan antara jenis aplikasi utilities dengan jumlah iklan yang terpasang pada aplikasi tersebut adalah very low negative correlation. Karena adanya hubungan very low negative correlation tersebut, kecil kemungkinan antara dua variabel tersebut saling berkorelasi. Dari hubungan tersebut dapat diterjemahkan bahwa jumlah iklan yang terpasang pada utilities memiliki hubungan yang berbanding terbalik dengan aplikasi utilities. Semakin sedikit aplikasi utilities yang diunduh maka jumlah iklan yang terdapat pada aplikasi tersebut semakin banyak.

Untuk aplikasi ketiga yang akan dihitung korelasinya dengan jumlah iklan yang terpasang adalah aplikasi entertainment seperti games, multimedia player, dan lain-lain. Perhitungan menggunakan rumus yang sama sepertipersamaan 2, diperoleh:

$$
\begin{gathered}
r_{x y}=\frac{46 \times 112-32 \times 141}{\sqrt{46 \times 128-(32)^{2} \times\left(46 \times 855-(141)^{2}\right.}} \\
r_{x y}=\frac{640}{\sqrt{4864 \times 19949}}=0.065
\end{gathered}
$$

Dari perhitungan di atas, diperoleh nilai korelasi sebesar 0.065. Hal ini mengindikasikan bahwa hubungan antara jenis aplikasi entertainment dengan jumlah iklan yang terpasang pada aplikasi tersebut adalah very low positive correlation. Karena adanya hubungan very low positive correlation tersebut, kecil kemungkinan antara dua variabel tersebut saling berkorelasi. Dengan adanya hubungan tersebut, dapat diterjemahkan bahwa jumlah iklan yang terpasang pada aplikasi entertainment tidak terlalu memiliki hubungan dengan aplikasi tersebut.

Berdasarkan perhitungan ukuran korelasi dari aplikasi social networks dan entertainment diperoleh hubungan korelasi very low positive. Dari adanya hubungan korelasi yang dihasilkan, prediksi awal peneliti yang mengatakan bahwa tingkat kepopuleran suatu aplikasi akan memengaruhi jumlah iklan yang terdapat pada aplikasi tersebut adalah salah. Dengan dihasilkannya hubungan korelasi very low positive, maka jenis aplikasi yang populer seperti social networks dan entertainment tidak akan memengaruhi jumlah iklan yang terdapat pada aplikasi-aplikasi tersebut. Sedangkan untuk aplikasi utilities yang hubungannya very low negative, juga tidak akan memengaruhi keberadaan jumlah iklan pada aplikasi tersebut. Hanya karena korelasinya bernilai negatif, maka jika aplikasi utilities sedikit yang unduh maka jumlah iklan yang terdapat pada aplikasi tersebut akan banyak.

Analisis Survey Kedua. Berdasarkan hasil survey pertama, terlihat bahwa aplikasi social network merupakan aplikasi yang paling sering digunakan oleh pengguna smartphone. Oleh karena itu, pada survey kedua, akan dilakukan penelitian untuk mencari tahu apakah iklan dari aplikasi social networks efektif atau tidak dilihat dari jumlah pengguna yang melakukan klik pada aplikasi tersebut. Cara perhitungan korelasi hampir sama dengan survey pertama. Berdasarkan rumus yang sama seperti persamaan 2 diperoleh:

$$
r_{x y}=\frac{46 \times 8-29 \times 11}{\sqrt{46 \times 29-(29)^{2} \times\left(46 \times 11-(11)^{2}\right.}}
$$




$$
r_{x y}=\frac{49}{\sqrt{493 \times 385}}=0.112
$$

Dari perhitungan di atas, diperoleh nilai korelasi sebesar 0.112. Hal ini mengindikasikan bahwa hubungan yang terjadi antara aplikasi social networks dengan jumlah pengguna yang melakukan klik pada aplikasi tersebut adalah very low positive correlation. Karena adanya hubungan very low positive correlation tersebut, kecil kemungkinan antara dua variabel tersebut saling berkorelasi. Dari adanya hubungan tersebut, juga dapat disimpulkan bahwa aplikasi yang paling banyak diunduh oleh pengguna smartphone yaitu social networks tidak akan memengaruhi pengguna untuk melakukan klik terhadap iklan yang terpasang pada aplikasi tersebut.

\section{Kesimpulan}

Berdasarkan analisis hasil survey yang telah peneliti lakukan, didapat dua poin kesimpulan. Pertam, jenis aplikasi tidak memengaruhi jumlah iklan yang terpasang pada aplikasi tersebut. Dengan kata lain, perusahaan yang memasang iklan pada aplikasi mobile tidak menjadikan jenis aplikasi sebagai pertimbangan untuk memutuskan tindakan pemasangan iklan. Perusahaan nampaknya memilih jenis aplikasi untuk pemasangan iklan secara random, tidak ada ketentuan jenis aplikasi tertentu untuk dipilih perusahaan dalam pemasangan iklan. Kedua, jumlah pengunduh aplikasi tidak memengaruhi pengguna yang melakukan klik pada iklan dalam aplikasi. Dengan kata lain, kepopuleran sebuah aplikasi berdasarkan jumlah pengunduhnya, belum tentu menjamin iklan yang terpasang pada aplikasi tersebut akan di-klik oleh pengguna aplikasi tersebut.

Berdasarkan analisis hasil survey yang peneliti dapatkan, dapat disimpulkan bahwa pemasangan iklan pada aplikasi mobile smartphone tidaklah efektif sebab reaksi dari para pengguna aplikasi terhadap iklan yang mereka lihat cenderung negatif. Sebagian besar pengguna mengaku tidak pernah membuka link iklan yang mereka lihat selama menggunakan aplikasi mobile. Hal ini menandakan keputusan untuk melanjutkan pemasangan iklan pada aplikasi mobile tidak efisien. Dapat disimpulkan juga bahwa popularitas aplikasi bukanlah faktor yang memengaruhi efektivitas iklan. Hal ini dapat dibuktikan dengan rendahnya korelasi antara kepopuleran aplikasi dengan jumlah klik ikla yang dilakukan penerima iklan pada aplikasi tersebut.
Selain menampilkan nilai korelasi antara jenis aplikasi dan jumlah iklan, proses analisis data hasil survey juga memberikan gambaran kriteria pemasangan iklan yang efektif pada aplikasi mobile. Data kriteria ini akan peneliti rekomendasikan untuk para perusahaan yang masih ingin meneruskan kegiatan pemasaran produk maupun jasa melalui pemasangan iklan pada aplikasi mobile smartphone.

Terdapat 3 kriteria pemasangan iklan pada aplikasi mobile smartphone yang direkomendasikan bagi perusahaan. Pertama, iklan yang ditampilkan ke pengguna aplikasi adalah iklan yang sesuai dengan kebutuhan masing-masing pengguna. Untuk dapat mewujudkan iklan yang sesuai kebutuhan, harus disertai dengan penerapan lebih lanjut teknik user profiling. Kedua, tampilkan iklan dengan bahasa yang lugas, sederhana, informatif, berpenampilan menarik, persuasif, memiliki efek yang menarik, dan berpenampilan unik. Ketiga, bila mungkin, sediakan pilihan-pilihan jenis iklan pada aplikasi mobile yang digunakan, dengan demikian para pengguna dapat memilih sendiri jenis iklan mana yang paling menarik, dan paling sesuai dengan kebutuhan.

\section{Referensi}

[1] N. Scott \& I. Respini, Ovum Forecasts 20012005: Global Mobile Markets, Ovum Ltd., London, 2001.

[2] C. Interactive, "The Future of Wireless Marketing," pp. 1-11, 2002.

[3] M. Leppäniemi \& H. Karjaluoto, "Factors Influencing Consumers' Willingness to Accept Mobile Advertising: A Conceptual Model," International Journal of Mobile Communications, vol. 3, pp. 197-213, 2005.

[4] M. Leppäniemi, "Mobile Marketing Communications in Consumer Markets," Ph.D Thesis, Faculty of Economics and Business Administration, University of Oulu, 2008.

[5] G. Drury, "Opinion Piece: Social Media: Should Marketers Engage and How Can It Be Done Effectively?," Journal of Direct, Data and Digital Marketing Practice, vol. 9, pp. 274-277, 2008.

[6] P. Barwise \& C. Strong, "Permission-based Mobile Advertising," Journal of Interactive Marketing, vol. 16, pp. 14-24, 2002.

[7] P. Golding, Next Generation Wireless Applications: Creating Mobile Applications 
in A Web 2.0 and Mobile 2.0 World, 2nd ed, John Wiley and Sons, New Jersey, 2008.

[8] C. Spurgeon, "Losers and Lovers: Mobile Phone Services Adveritising and the New Media Consumer/Producer," Journal of Interactive Advertising, vol. 5, pp. 47-55, 2005.

[9] S. Allen, V. Graupera, \& L. Lundrigan, Pro Smartphone Cross-Platform Development: iPhone, Blackberry, Windows Mobile and Android Development and Distribution, Apress, New York, 2010.

[10] J.W. Lee, C.S. Lee, \& Y.S. Park, "Research on the Advertisement Effect of Push Type Mobile Advertisement" In IEEE Fourth International Conference on Cooperation and Promotion of Information Resources in Science and Technology, pp. 137-142, 2009.

[11] T. De Pessemier, T. Deryckere, K. Vanhecke, \& L. Martens, "Proposed Architecture and Algorithm for Personalized Advertising on iDTV and Mobile Devices," IEEE Transactions On Consumer Electronics, vol. 54, pp. 709-713, 2008.

[12] D. Drossos \& G.M. Giaglis, "Mobile Advertising Effectiveness: an Exploratory Study" In Proceedings of the International Conference on Mobile Business, p. 2, 2006.
[13] Y.C. Lee, "Factors Influencing Attitudes towards Mobile Location-based Advertising," In Software Engineering and Service Sciences (ICSESS), 2010 IEEE International Conference, pp. 709-712, 2010.

[14] M.M. Tsang, S.C. Ho, \& T.P. Liang, "Consumer Attitudes Toward Mobile Advertising: An Empirical Study," International Journal of Electronic Commerce, vol. 8, pp. 65-78, 2004.

[15] H. Lee, J.G. Kim, S. J. Yang, \& J. Hong, "Personalized TV Services based on TVanytime for Personal Digital Recorder," IEEE Trans. Consumer Electron, vol. 51, pp.885-892, 2005.

[16] D.E. Hinkle, W. Wiersma, \& S.G. Jurs, Applied Statistics for the Behavioral Sciences, 5th Edition, Houghton Mifflin Company, New York, 2003.

[17] S.L. Jackson, Research Methods and Statistics: A Critical Thinking Approach, $3^{\text {rd }}$ Edition, Cengage Learning, New York , 2008.

[18] H. Lin, "The Communication Between Advertising Research and Other Disciplines: A Citation Analysis," Asia Pacific Management Review, vol. 2, pp. 1-12, 2000.

[19] R. Unni \& R. Harmon, "Perceived Effectiveness of Push vs. Pull Mobile Location-based Advertising," Journal of Interactive Advertising, vol. 7, pp. 1-24, 2007. 